\title{
Hubungan Aktivitas Duduk Lama Dengan Keluhan Musculoskeletal Pada Punggung Bawah: Critical Review \\ ${ }^{1}$ Rahayu Gita Junita, ${ }^{2}$ Arif Pristianto, ${ }^{3}$ Arin Supriyadi, ${ }^{4}$ Taufik Eko Susilo
}

Program Studi Fisioterapi, Fakultas Kesehatan, Universitas Muhammadiyah SurakartaJl. Ahmad Yani, Pabelan, Kartasura, Surakarta, Jawa Tengah, Indonesia 57162

Email: ums@ums.ac.id

\begin{abstract}
ABSTRAK
Latar belakang: Duduk dengan waktu yang lama dapat meningkatkan ketegangan pada otot punggung serta pinggul dan menimbulkan ketegangan pada persendian dalam posisi statis untuk waktu yang lama. Otot punggung mengalami kontraksi yang berlebihan, kemudian untuk menahan dan mempertahankan posisi duduk, otot menjadi spasm atau tightness. Nyeri pada punggung bawah adalah kondisi musculoskeletal yang paling umum ditemukan. Tujuan: Penelitian ini bertujuan untuk meriview artikel penelitian terdahulu tentang hubungan aktivitas duduk lama dengan keluhan musculoskeletal pada punggung bawah. Metode: Metode penelitian menggunakan critical review dan pencarian data dilakukan untuk mengidentifikasi metode cross sectional observational menggunakan mesin pencarian literatur seperti pubmed central (PMC) dan google scholar, kemudian dilanjutkan dengan mengidentifikasi jenis quartile (Q1-4) menggunakan mesin pencarian scimago journal and country rank (SJR) dan penilaian dengan quality assessment tool for observational cohort and cross-sectional study. Hasil: Didapatkan hasil sebanyak 9 artikel yang digunakan sebagai landasan penelitian yang disesuaikan dari kriteria inklusi, dilakukan review artikel, disesuaikan dengan kaidah what, who, where, when hingga dinilai dengan quality assessment tool for observational cohort and cross-sectional study. Kesimpulan: Penelitian menunjukkan adanya hubungan yang signifikan pada aktivitas duduk lama dengan keluhan musculoskeletal pada punggung bawah.
\end{abstract}

Kata Kunci: Aktivitas duduk lama, gangguan muskuloskeletal, nyeri punggung bawah.

\section{ABSTRACT}

Background: Sitting on chair for eight hours or more can increase the tension on back and hip muscles such as hamstring, iliopsoas, piriformis, and raises tension on joints during constant potition for a long periods of time. The back muscles are experiencing excessive contractions, then to maintain the sitting position, the muscles become spasm or tighness. Pain on lower back is the most common muculoskeletal condition. Purpose: This research purpose is to review the previous research about the relation between sitting for a long period of time with musculoskeletal on lower back complaint. Method: The research method used critical review and the data finding had been done to identify cross sectional observational method used literary search engine such as pubmed central (PMC) and google scholar, afterwards continued by identity the quartile (Q1-4) type used scimago journal and country rank (SJR) search engine and assessment with quality assessment tool for observational cohort and cross-sectional study. Findings: There was 9 articles found that had been used as the research foundation which was adjusted from inclusion criteria, articles review had been done by adapted to the rules what, who, where, when until assessed with quality assessment tool for observational cohort and cross-sectional study. Conclusions: The research shows there are significant relation on sitting for a periods of time with lower back musculoskeletal complaint.

Key words: Sitting for a periods of time, musculoskeletal disorders, lower back pain. 
R.G Junita., A Pristianto., A Supriyadi. \& T.E Susilo Fisiomu.2021 Vol 2(3): 150-161

DOI: $10.23917 /$ fisiomu.v2i3.15199

\section{Pendahuluan}

Gaya hidup sedenter didefinisikan sebagai perilaku yang melibatkan sedikit gerakan fisik dan ditandai dengan pengeluaran energi $\leq 1,5$ METs, saat dalam posisi duduk atau berbaring (Magnon et al., 2018). Gaya hidup sedenter memiliki dampak buruk bahkan kematian seperti yang dijelaskan Thivel et al. (2018) 5,3 juta kematian disebabkan oleh pola hidup sedenter, literatur dengan analisis meta terbaru memberikan bukti tingkat tinggi mengenai dampaknya pada kematian secara keseluruhan. Stamatakis et al. (2019) menjelaskan studi pertama tentang duduk dan risiko kematian yang menggunakan pendekatan analitik komprehensif, ditemukan bahwa waktu duduk yang lebih lama dikaitkan dengan risiko kematian cardiovascular disease (CVD) yang lebih tinggi.

Duduk di kursi selama delapan jam atau lebih dapat meningkatkan ketegangan pada otot punggung serta pinggul dan menimbulkan ketegangan pada persendian dalam posisi statis untuk waktu yang lama. Otot punggung mengalami kontraksi yang berlebihan, kemudian untuk menahan dan mempertahankan posisi duduk, otot menjadi spasm atau tightness (Mondal et al., 2017).

Penurunan gerakan fisik dan kegiatan berpengaruh terhadap penurunan masa otot serta menyebabkan munculnya musculoskeletal disorders (MSDs) (Davies et al., 2019). Berdasarkan penelitian yang telah dilakukan oleh (Soares et al., 2019) gangguan musculoskeletal (MSDs) ditandai dengan adanya ketidaknyamanan, ketidakmampuan atau nyeri terus-menerus pada otot, tendon, persendian, ligamen, tulang, saraf, dan sistem sirkulasi darah yang cenderung menyebabkan ketidakseimbangan fungsional, disebabkan atau diperburuk oleh gerakan berulang dan postur tubuh yang buruk atau dilakukan dalam waktu lama (Muralidharan et al., 2013).

Populasi yang rentan terhadap terjadinya MSDs adalah seseorang yang menghabiskan sebagian besar waktunya dengan duduk, biasanya karena sifat pekerjaan (Hanna et al., 2019). Morris et al. (2018) mengatakan bahwa nyeri pada punggung bawah adalah kondisi musculoskeletal yang paling umum ditemukan di antara negara maju dan berkembang. Secara global, tahun-tahun hidup dengan kecacatan yang disebabkan oleh nyeri pada punggung bawah meningkat sebesar $54 \%$ antara tahun 1990 dan 2015 (Hartvigsen et al., 2018).

Berdasarkan penelitian yang telah dilakukan oleh Madinei et al. (2018) cedera di punggung bawah biasanya diakibatkan oleh respon mendadak terhadap pembebanan yang tiba-tiba. Rasa sakit yang dialami saat duduk dikaitkan dengan peningkatan tekanan dan beban intradiscal pada tulang belakang bagian bawah dalam posisi duduk, peningkatan aktivitas dan kerja otot, lumbal lordosis dan akibatnya peningkatan stres pada otot dan ligamen di sekitarnya (Mbada et al., 2016).

Berdasarkan penelitian yang telah dilakukan oleh Pillai and Haral (2018) aktivitas duduk dalam waktu yang lama menyebabkan nyeri pada punggung bawah. Penelitian ini memiliki perbedaan dengan penelitian Korshøj et al. (2018) yang mengatakan durasi aktivitas duduk tidak menimbulkan risiko nyeri pada punggung bawah diantara populasi pekerja yang terutama berasal dari pekerja kantoran.

\section{Metode}

Penelitian ini menggunakan metode critical review. Critical review merupakan metode penelitian dengan cara analisis dan evaluasi dari sebuah buku, artikel, jurnal atau media lainnya. Tujuan penulisan critical review yaitu untuk mengungkapkan suatu sudut 
R.G Junita., A Pristianto., A Supriyadi. \& T.E Susilo

Fisiomu.2021 Vol 2(3): 150-161

pandang penulis tentang infrormasi yang diperoleh. Pencarian data dilakukan dengan mengidentifikasi metode cross sectional observtional menggunakan mesin pencarian literatur seperti pubmed central (PMC) dan google scholar dengan menggunakan kata kunci "musculoskeletal" atau "sitting", kemudian digabungkan dengan beberapa kata kunci lainnya. Kombinasi kata kunci seperti musculoskeletal disorders and sitting duration, musculoskeletal disorders and prolonged sitting, back problem and sitting duration, back problem and prolonged sitting.

Setelah mendapat artikel kemudian dilanjutkan dengan mengidentifikasi jenis quartile (Q1-4) dari artikel yang ditemukan, menggunakan mesin pencarian scimago journal and country rank (SJR). Kemudian dilanjutkan dengan tahapan appraisal ini yaitu quality assessment tool for observational cohort and cross-sectional study. Quality assessment tool for observational cohort and cross-sectional study adalah alat yang digunakan untuk mengukur kualitas risiko bias yang akan terjadi dan diberikan dalam jenis penelitian observational cross sectional. Terdapat 14 poin yang diukur dalam skala ini, dengan cara penilaian yaitu dikatakan YA jika poinnya terdapat dalam artikel, dikatakan TIDAK jika poinnya tidak terdapat dalam artikel atau dikatakan LAINNYA apabila tidak masuk dalam penilaian dalam YA dan Tidak, jika CD (tidak dapat menentukan), NA (tidak berlaku) NR (tidak dilaporkan).

\section{Hasil}

Hasil yang didapatkan dari penilitian ini memiliki tujuan untuk mengetahui adanya hubungan aktivitas duduk lama dengan keluhan musculoskeletal pada punggung bawah. Penelitian ini juga memiliki tujuan yang lebih spesifik seperti menjelaskan tentang keluhan musculoskeletal pada punggung bawah, menjelaskan tentang aktivitas duduk, serta hubungan antara aktivitas duduk dengan keluhan musculoskeletal pada punggung bawah. Penelitian ini menggunakan metode penelitian critical review dan studi obsevational cohort and cross cectional untuk mendapatkan hasil.

Alur studi pencarian artikel, dengan total pencarian data 583 artikel menggunakan basis pencarian pubmed central (PMC) dan google scholar, dimana tersisa 269 setelah duplikat dihapus. Setelah penyaringan judul, 246 penelitian lebih lanjut dihapus dan didapatkan 23 artikel full text hasil proses skrining, 14 studi dihapus dengan 5 dikecualikan karena tidak terindeks scopus, 6 artikel tidak terdapat di scimago dan 3 artikel tidak memiliki hasil yang sesuai dengan tema penelitian. Maka terdapat 9 artikel yang akan di review.

Dari kesembilan artikel yang telah terpilih sebagai landasan dalam studi ini, semuanya telah dilakukan pengecekan quartile menggunakan scimago journal and country rank $(S J R)$, dan penilaian ukuran valid dari kualitas metodologi uji klinis menggunakan quality assessment tool for observational cohort and cross-sectional study.

Dari kesembilan artikel yang telah terpilih sebagai landasan dalam studi ini, semuanya telah dilakukan pengecekan quartile menggunakan scimago journal and country rank (SJR), dan penilaian ukuran valid dari kualitas metodologi uji klinis menggunakan quality assessment tool for observational cohort and cross-sectional study. Tahapan pecarian artikel beserta pengecualian artikel dapat dilihat pada gambar 1. 
R.G Junita., A Pristianto., A Supriyadi. \& T.E Susilo Fisiomu.2021 Vol 2(3): 150-161 DOI: $10.23917 /$ fisiomu.v2i3.15199

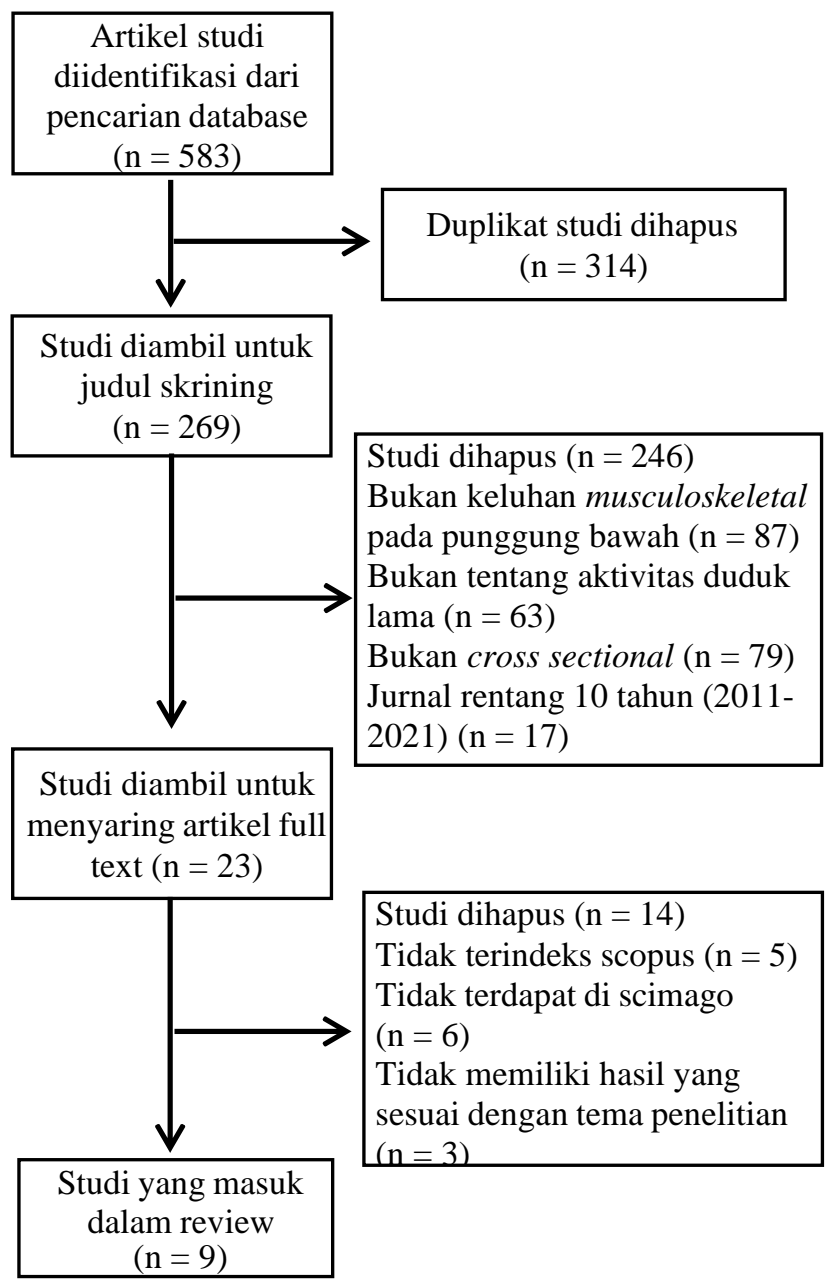

Gambar.1. Pencarian Artikel

Setelah dilakukan pengecekan quartile dan penilaian quality assessment tool for observational cohort and cross-sectional study, didapatkan hasil bahwa dua artikel memiliki nilai Q1, empat artikel memiliki nilai Q2, satu artikel memiliki nilai Q3, dan dua artikel memiliki nilai Q4. Semua artikel memiliki tujuan penelitian yang jelas, dan populasi penelitian ditentukan serta didefinisikan dengan jelas. Satu artikel tidak memiliki partisipasi responden yang memenuhi syarat, sedangkan kedelapan artikel memiliki partisipasi responden yang memenuhi syarat. Semua artikel menggunakan responden dari populasi yang sama dan kriteria kelayakan yang seragam.
Kedua artikel tidak menjelaskan alasan atau ukuran sampel. sedangkan ketujuh artikel menjelaskan alasan atau ukuran sampel. Semua artikel tidak memiliki kriteria keterpaparan tidak dinilai sebelum pengukuran hasil dan tidak memliki jangka waktu yang cukup untuk melihat efeknya.

Ketiga artikel tidak menjelaskan tingkat pemaparan atau keterpaparan, sedangkan keenam artikel menjelaskan tingkat pemaparan tau keterpaparan. Kelima artikel tidak memiliki pengukuran keterpaparan yang jelas, sedangkan keempat artikel memiliki pengukuran keterpaparan yang jelas. Semua artikel tidak melakukan penilaian lebih dari satu kali serta tidak mengetahui status keterpaparan responden. Satu artikel tidak memiliki kriteria pengukuran hasil yang valid atau objektif, sedangkan kedelapan artikel memiliki kriteria tersebut. Dua artikel memiliki kriteria mangkir setelah tindak lanjut kurang dari 20\%, sedangkan ketujuh artikel tidak memiliki kriteria mangkir setelah tindak lanjut. Satu artikel tidak menjelaskan variabel perancu potensial utama secara statistik, sedangkan kedelapan artikel menjelaskan variabel perancu potensial utama secara statistik.

Dari keseluruhan artikel, disimpulkan total nilai appraisal yang didapat dari pengukuran skala quality assessment tool for observational cohort and cross-sectional studies yaitu terdapat empat artikel bernilai baik, yang artinya memiliki risiko bias rendah, sedangkan lima artikel bernilai sedang yang artinya memiliki risiko bias sedang. 
Tabel .1. Review Artikel

\begin{tabular}{|c|c|c|c|c|}
\hline Penulis & Population & $\begin{array}{c}\text { Faktor risiko } \\
\text { lainnya }\end{array}$ & Hasil & Kesimpulan \\
\hline $\begin{array}{l}\text { (Warner et } \\
\text { al, 2018) }\end{array}$ & $\begin{array}{l}\text { Subjek dalam penelitian ini } \\
\text { adalah } 113 \text { mahasiswa laki- } \\
\text { laki yang memiliki riwayat } \\
\text { nyeri pantat. }\end{array}$ & $\begin{array}{l}\text { Postur tubuh yang } \\
\text { buruk, kebiasaan } \\
\text { makan } r \text { yang } \\
\text { buruk, gangguan } \\
\text { tidur dan tonus } \\
\text { otot lemah. }\end{array}$ & $\begin{array}{l}\text { Penelitian menunjukkan } 5 \% \\
\text { prevalensi piriformis syndrome } \\
\text { pada mahasiswa laki-laki, } \\
\text { berhubungan dengan duduk lama, } \\
\text { kelemahan otot dan postur tubuh } \\
\text { yang buruk. }\end{array}$ & $\begin{array}{l}\text { Aktivitas duduk lama berhubungan } \\
\text { dengan keluhan musculoskeletal } \\
\text { pada punggung bawah ditambah } \\
\text { dengan faktor lain seperti postur } \\
\text { tubuh yang buruk, kebiasaan } \\
\text { makan yang buruk, gangguan tidur } \\
\text { dan tonus otot lemah. }\end{array}$ \\
\hline $\begin{array}{l}\text { (Desai and } \\
\text { Anand, } \\
\text { 2020) }\end{array}$ & $\begin{array}{l}\text { Subjek dalam penelitian ini } \\
\text { adalah } 260 \text { individu. Terdiri } \\
\text { dari } 162 \text { laki-laki dan } 98 \\
\text { perempuan. Bekerja sebagai } \\
\text { pegawai bank. }\end{array}$ & $\begin{array}{l}\text { Indeks masa tubuh } \\
\text { (BMI) dan faktor } \\
\text { risiko ergonomis. }\end{array}$ & $\begin{array}{l}\text { Menurut penelitian terdapat } 51 \% \\
\text { prevalensi piriformis tightness } \\
\text { pada bankers. Alasannya karena } \\
\text { banyak waktu yang dihabiskan } \\
\text { dalam posisi duduk. }\end{array}$ & $\begin{array}{l}\text { Aktivitas duduk lama berhubungan } \\
\text { dengan keluhan musculoskeletal } \\
\text { pada punggung bawah ditambah } \\
\text { dengan faktor lain yaitu indeks } \\
\text { masa tubuh (BMI). }\end{array}$ \\
\hline $\begin{array}{l}\text { (Gupta et } \\
\text { al., 2015) }\end{array}$ & $\begin{array}{l}\text { Subjek dalam penelitian } \\
\text { sebanyak } 201 \text { individu. } \\
\text { Terdiri dari } 117 \text { laki-laki dan } \\
84 \text { perempuan. Bekerja } \\
\text { sebagai pekerja buruh. }\end{array}$ & $\begin{array}{l}\text { Merokok, } \\
\text { pengaruh di } \\
\text { tempat kerja, dan } \\
\text { senioritas } \\
\text { pekerjaan. }\end{array}$ & $\begin{array}{l}\text { Pekerja dengan waktu duduk } \\
\text { tinggi memiliki kemungkinan } \\
\text { yang jauh lebih tinggi untuk } \\
\text { melaporkan intensitas LBP yang } \\
\text { tinggi, baik untuk total maupun } \\
\text { waktu duduk santai. }\end{array}$ & $\begin{array}{l}\text { Aktivitas duduk lama berhubungan } \\
\text { dengan keluhan musculoskeletal } \\
\text { pada punggung bawah. Faktor } \\
\text { risiko lainnya tidak berhubungan } \\
\text { dengan keluhan musculoskeletal } \\
\text { pada punggung bawah. }\end{array}$ \\
\hline $\begin{array}{l}\text { (Hanna et } \\
\text { al., 2019) }\end{array}$ & $\begin{array}{l}\text { Subjek dalam penelitian } \\
\text { adalah } 479 \text { karyawan. Terdiri } \\
\text { dari } 240 \text { staf akademik dan } \\
239 \text { staf profesional. } \\
\text { Terdiri dari laki-laki dan } \\
\text { perempuan. Bekerja sebagai } \\
\text { karyawan Universitas. }\end{array}$ & $\begin{array}{l}\text { Suasana hati yang } \\
\text { buruk atau stres } \\
\text { dan physical } \\
\text { activity. }\end{array}$ & $\begin{array}{l}\text { Responden yang melaporkan } \\
\text { duduk terlalu lama lebih } \\
\text { cenderung mengalami nyeri } \\
\text { punggung bawah atau atas. Jenis } \\
\text { kelamin wanita secara signifikan } \\
\text { lebih mungkin mengalami UBP } \\
\text { atau LBP daripada laki-laki. }\end{array}$ & $\begin{array}{l}\text { Aktivitas duduk lama berhubungan } \\
\text { dengan keluhan musculoskeletal } \\
\text { pada punggung bawah ditambah } \\
\text { dengan faktor lain yaitu suasana } \\
\text { hati yang buruk atau stres dan } \\
\text { physical activity. }\end{array}$ \\
\hline $\begin{array}{l}\text { (Bontrup } \\
\text { et al., } \\
\text { 2019) }\end{array}$ & $\begin{array}{l}\text { Subjek dalam penelitian ini } \\
\text { adalah 64.Terdiri dari laki- } \\
\text { laki dan perempuan.Bekerja } \\
\text { sebagai pekerja kantor call } \\
\text { center professional }\end{array}$ & Posisi duduk. & $\begin{array}{l}\text { Subjek dengan nyeri dan } \\
\text { ketidakmampuan terkait nyeri } \\
\text { menunjukkan duduk yang lebih } \\
\text { statis dibandingkan dengan subjek } \\
\text { tanpa rasa sakit. Terdapat } \\
\text { hubungan antara perilaku duduk } \\
\text { dan subjek yang melaporkan LBP } \\
\text { kronis. }\end{array}$ & $\begin{array}{l}\text { Aktivitas duduk lama berhubungan } \\
\text { dengan keluhan musculoskeletal } \\
\text { pada punggung bawah ditambah } \\
\text { dengan faktor lain yaitu posisi } \\
\text { duduk. }\end{array}$ \\
\hline
\end{tabular}


Tabel .2. Review Artikel

\begin{tabular}{|c|c|c|c|c|}
\hline Penulis & Population & $\begin{array}{c}\text { Faktor risiko } \\
\text { lainnya }\end{array}$ & Hasil & Kessimpulan \\
\hline $\begin{array}{l}\text { (Kanyenye } \\
\text { ri, } \\
\text { Asiimwe, } \\
\text { Mochama, } \\
\text { \& } \\
\text { Nyiligira, } \\
\text { 2017) }\end{array}$ & $\begin{array}{l}\text { Subjek dalam } \\
\text { penelitian ini adalah } \\
144 \text { dari } 226 \\
\text { populasi Terdiri dari } \\
80 \text { laki-laki dan } 64 \\
\text { perempuan. Bekerja } \\
\text { sebagai pegawai } \\
\text { bank. }\end{array}$ & $\begin{array}{l}\text { Posisi duduk, } \\
\text { merokok, dan } \\
\text { alkohol. }\end{array}$ & $\begin{array}{l}\text { Durasi jam yang dihabiskan untuk } \\
\text { penggunaan komputer memiliki } \\
\text { hubungan signifikan dengan nyeri } \\
\text { punggung, responden yang } \\
\text { menghabiskan } 10 \text { hingga } 12 \text { jam per } \\
\text { hari 3,5 kali lebih mungkin } \\
\text { mengalami nyeri punggung } \\
\text { dibandingkan dengan menggunakan } \\
\text { komputer selama 4-6 jam. }\end{array}$ & $\begin{array}{l}\text { Aktivitas duduk lama berhubungan } \\
\text { dengan keluhan musculoskeletal pada } \\
\text { punggung bawah ditambah dengan faktor } \\
\text { lain seperti posisi duduk dan merokok. } \\
\text { Alkohol tidak mempengaruhi munculnya } \\
\text { keluhan musculoskeletal pada punggung } \\
\text { bawah. }\end{array}$ \\
\hline $\begin{array}{l}\text { (Wang et } \\
\text { al., 2017) }\end{array}$ & $\begin{array}{lr}\text { Subjek dalam } \\
\text { penelitian ini adalah } \\
719 \text { dari } 800 . \\
\text { Terdiri dari } 694 \\
\text { laki-laki dan } 25 \\
\text { perempuan. Bekerja } \\
\text { sebagai pengemudi } \\
\text { taksi. }\end{array}$ & $\begin{array}{lr}\text { Shift malam, } \\
\text { tahun kerja, hari } \\
\text { istirahat perbulan } \\
\text { termasuk jam } \\
\text { tidur dalam } \\
\text { sehari dan } \\
\text { aktivitas fisik, } \\
\text { perokok dan } \\
\text { peminum. }\end{array}$ & $\begin{array}{l}\text { Hasil analisis regresi logistik } \\
\text { univariat menunjukkan bahwa risiko } \\
\text { pelaporan LBP meningkat dengan } \\
\text { durasi mengemudi harian yang lebih } \\
\text { lama untuk durasi mengemudi } \\
\text { harian } 8-\geq 12 \text { jam. }\end{array}$ & $\begin{array}{l}\text { Aktivitas duduk lama berhubungan } \\
\text { dengan keluhan musculoskeletal pada } \\
\text { punggung bawah ditambah dengan faktor } \\
\text { lain yaitu shift malam, tahun kerja, hari } \\
\text { istirahat perbulan termasuk jam tidur } \\
\text { dalam sehari dan aktivitas fisik. Perokok } \\
\text { dan peminum tidak berhubungan dengan } \\
\text { munculnya keluhan musculoskeletal pada } \\
\text { punggung bawah. }\end{array}$ \\
\hline $\begin{array}{l}\text { (Šagát, } \\
\text { Bartík, } \\
\text { González, } \\
\text { Tohănean, } \\
\text { \& Knjaz, } \\
\text { 2020) }\end{array}$ & $\begin{array}{l}\text { Subjek dalam } \\
\text { penelitian ini adalah } \\
\text { 463individu. Terdiri } \\
\text { dari } 330 \text { warga } \\
\text { negara saudi dan } \\
133 \text { orang asing, } \\
259 \text { laki-laki dan } \\
204 \text { perempuan. }\end{array}$ & $\begin{array}{l}\text { Stres dan } \\
\text { penurunan } \\
\text { physical activity } \\
\text { mingguan. }\end{array}$ & $\begin{array}{l}\text { Responden yang duduk hampir } \\
\text { sepanjang waktu selama karantina } \\
\text { meningkat secara signifikan. } \\
\text { Ditemukan adanya hubungan } \\
\text { signifikan antara intensitas LBP dan } \\
\text { waktu yang dihabiskan untuk duduk } \\
\text { selama karantina. }\end{array}$ & $\begin{array}{l}\text { Aktivitas duduk lama berhubungan } \\
\text { dengan keluhan musculoskeletal pada } \\
\text { punggung bawah ditambah dengan faktor } \\
\text { lain seperti stres dan penurunan physical } \\
\text { activity mingguan. }\end{array}$ \\
\hline $\begin{array}{l}\text { (Dagne et } \\
\text { al., 2020) }\end{array}$ & $\begin{array}{lr}\text { Subjek } & \text { dalam } \\
\text { penelitian ini adalah } \\
755 \quad \text { dari } & 838 \\
\text { populasi. } & \text { Terdiri } \\
\text { dari } 383 \text { perempuan } \\
\begin{array}{lr}\text { dan } 372 & \text { laki-laki } \\
\text { yang } & \text { bekerja } \\
\text { sebagai } & \text { pegawai } \\
\text { bank. }\end{array}\end{array}$ & $\begin{array}{l}\text { Postur yang } \\
\text { buruk, tidak ada } \\
\text { waktu istirahat, } \\
\text { jenis kursi dan } \\
\text { stres kerja. }\end{array}$ & $\begin{array}{l}\text { Empat daerah tubuh yang paling } \\
\text { sering merasakan nyeri adalah } \\
\text { punggung bawah } 54,3 \% \text {, bahu } \\
40,9 \% \text {, leher } 38,0 \% \text {, dan punggung } \\
\text { atas } 35,4 \% \text {,. Mayoritas, } 97 \% \text { pekerja } \\
\text { bank melakukan kebiasaan kerja } \\
\text { dengan duduk } 2 \text { sampai } 2 \text { jam lebih } \\
\text { dalam satu waktu tanpa berpindah } \\
\text { tempat. }\end{array}$ & $\begin{array}{l}\text { Aktivitas duduk lama berhubungan } \\
\text { dengan keluhan musculoskeletal pada } \\
\text { punggung bawah ditambah dengan faktor } \\
\text { lain yaitu postur yang buruk, tidak ada } \\
\text { waktu istirahat, jenis kursi dan stres } \\
\text { kerja. }\end{array}$ \\
\hline
\end{tabular}

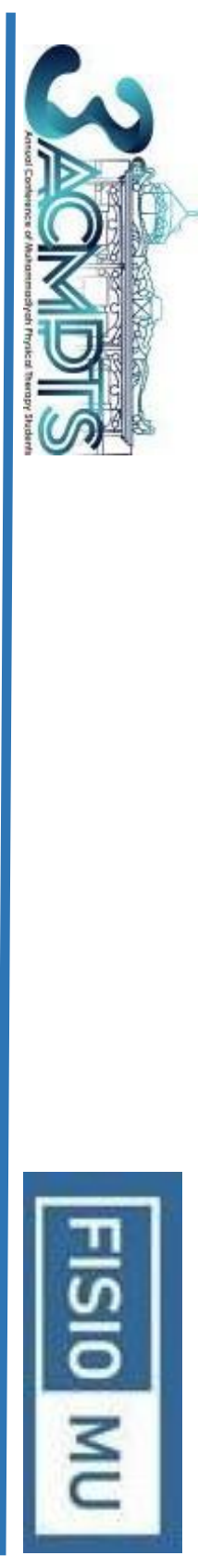




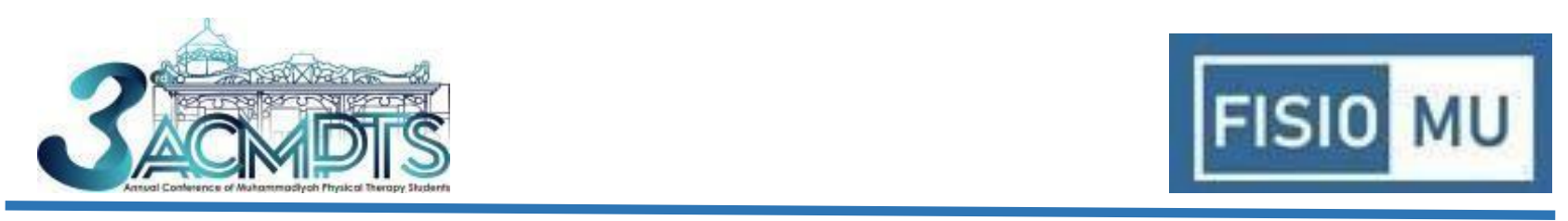

R.G Junita., A Pristianto., A Supriyadi. \& T.E Susilo Fisiomu.2021 Vol 2(3): 150-161

\section{Pembahasan}

Berdasarkan hasil review pada kesembilan artikel, maka untuk melihat hubungan aktivitas duduk lama dengan keluhan musculoskeletal pada punggung bawah dapat dilihat melalui banyak hal seperti jenis kelamin, usia subjek, pekerjaan, prevalensi, faktor risiko lainnya, dan kekuatan peneltitian. Berdasarkan penelitian Warner et al. (2018) populasi subjek yang dipakai yaitu mahasiswa laki-laki berusia 22-23 tahun, penelitian ini mengatakan bahwa dalam artikel ini hanya siswa laki-laki yang diizinkan untuk berpartisipasi. Sedangkan pada kedelapan artikel menggunakan responden dengan jenis kelamin laki-laki dan perempuan, memiliki rentan usia 18-65 tahun.

Subjek dalam kesembilan artikel memiliki jenis pekerjaan yang berbeda-beda, satu artikel adalah mahasiswa, tiga artikel memiliki pekerjaan sebagai bankers, satu artikel adalah pekerja buruh, satu artikel adalah karyawan universitas, satu artikel pekerja kantor, satu artikel sebagai supir taksi dan satu artikel tidak menjelaskan pekerjaan subjek dalam penelitian. Pekerjaan tersebut memiliki kebiasaan yang sama yaitu melakukan aktivitas duduk dalam jangka waktu lama. Berdasarkan penelitian yang dilakukan oleh Gupta et al. (2015) waktu duduk pekerja dibagi menjadi kategori waktu duduk total rendah $(6,4 \mathrm{jam})$, sedang (6,5-8,3 jam) dan tinggi (>8,3 jam) dalam sehari. Artikel Dagne et al. (2020) mengatakan pekerja bank melakukan aktivitas dengan duduk lama dalam ruang terbatas selama 2 jam atau lebih tanpa berpindah posisi.

Desai and Anand (2020) menjelaskan area lokasi nyeri pada bagian sakrum dengan prevalensi $51,92 \%$ yang terjadi pada pegawai bank sebagian besar berusia diatas 45 tahun.
DOI: $10.23917 /$ fisiomu.v2i3.15199

Berdasarkan penelitian yang telah dilakukan oleh Gupta et al. (2015) prevalensi terjadinya nyeri punggung bawah dibagi menjadi dua kategori yaitu rendah $84 \%$ dengan intensitas nyeri $<5$, sedangkan tinggi yaitu $16 \%$ dengan intensitas nyeri $>5$. Menurut Hanna et al. (2019) prevalensi LBP adalah 37,9\% yang terjadi pada pekerja karyawan universitas, 9,9\% usia 21-30 tahun, 17,4\% usia 31-40 tahun, 10,8\% diatas 40 tahun. Pada artikel Bontrup et al. (2019) prevalensi terjadinya nyeri pada punggung bawah adalah $75 \%$ dengan intensitas nyeri rendah hingga sedang pada pekerja professional call centre.

Berdasarkan penelitian yang telah dilakukan oleh O'sullivan et al. (2017) faktor fisik seperti postur tubuh dan posisi duduk, gaya hidup seperti istirahat dan physical activity, faktor sosial yaitu stres atau suasana hati yang buruk mempengaruhi tingkat terjadinya nyeri pada pungggung bawah. Berdasarkan penelitian yang telah dilakukan oleh Karunanayake et al. (2013) mengatakan bahwa BMI, tingkat pendapatan dan merokok tidak memiliki hubungan yang signifikan dengan nyeri pada punggung bawah.

Pembahasan selanjutnya adalah kekuatan penelitian dari kesembilan artikel. Keempat artikel tidak menjelaskan kekuatan penelitian, sedangkan kelima artikel menjelaskan kekuatan penilitian. Warner et al. (2018) menjelaskan kekuatan dari penelitiannya yaitu standar pengukuran, yang menggunakan dua tes untuk mengkonfirmasi piriformis syndrome. Kekuatan penelitian Gupta et al. (2015) adalah penggunaan ukuran objektif waktu duduk untuk menentukan hubungan waktu duduk dengan LBP. Akselerometer actigraph yang digunakan dalam penelitian ini tahan air dan mudah dipakai 
R.G Junita., A Pristianto., A Supriyadi. \& T.E Susilo Fisiomu.2021 Vol 2(3): 150-161

selama pengukuran jangka panjang. Kekuatan lainnya adalah penggunaan perangkat lunak tervalidasi, Acti4, untuk menentukan waktu duduk yang akurat. Hanna et al. (2019) menjelaskan kekuatan penelitiannya adalah instrumen yang digunakan diuji dan divalidasi secara ekstensif. Artikel selanjutnya adalah Kanyenyeri et al. (2017) mengatakan bahwa kekuatan penelitiannya adalah responden dipilih dengan teknik random sampling, regresi logistik telah dilakukan untuk mengukur faktor-faktor yang berhubungan dengan nyeri punggung. Wang et al. (2017) menjelaskan kekuatan utama dari penelitiannya adalah efektivitasnya dalam mewakili satu wilayah di Cina dan tingkat partisipasinya yang sangat tinggi (90\%).

\section{Kesimpulan dan Saran}

Berdasarkan hasil studi dengan menggunakan metode critical review, keseluruhan penelitian menunjukkan adanya hubungan antara aktivitas duduk lama dengan keluhan musculoskeletal pada punggung bawah. Faktor tambahan seperti postur tubuh yang buruk, posisi duduk, physical activity, istirahat, dan stres atau suasana hati yang buruk dapat mempengaruhi tingkat terjadinya keluhan musculoskeletal pada pungggung bawah. Sedangkan BMI, merokok, dan mengkonsumsi alkohol tidak berhubungan dengan tingkat terjadinya keluhan musculoskeletal pada punggung bawah.

Bagi studi selanjutnya, dalam penelitian selanjutnya dapat melakukan studi untuk mengetahui alasan pemelihan populasi sebagai responden, dan menggunakan usia dengan rentan yang tidak terlalu jauh. Bagi fisioterapis hasil studi critical review ini diharapkan dapat bermanfaat dan dapat dijadikan referensi serta
DOI: $10.23917 /$ fisiomu.v2i3.15199

menambah wawasan dalam mengindentifikasi durasi aktivitas duduk lama dengan keluhan musculoskeletal pada punggung bawah. Bagi masyarakat hasil studi critical review ini diharapkan dapat bermanfaat dan dapat dijadikan referensi serta dapat menjadi bahan pertimbangan baik pada penyelenggara pekerjaan, pekerja maupun masyarakat umum agar dilakukan kegiatan yang dapat mengurangi durasi aktivitas duduk. Sebaiknya, ada pembatasan waktu atau perbaikan tempat duduk sesuai ergonomis. Jika membutuhkan durasi duduk yang lama untuk melakukan suatu kegiatan atau menyelesaikan pekerjaan, perlu adanya kursi ergonomis untuk mengurangi terjadinya keluhan musculoskeletal pada punggung bawah.

\section{Ucapan Terimakasih}

Terimakasih saya ucapkan untuk dorongan dan dukungan orangtua dan teman teman saya, serta terimakasih karena penelitian ini dapat diselesaikan tidak lepas dari bimbingan dosen pembimbing saya bapak Arif Pristianto, dan para penguji sidang skripsi saya bapak Arin Supriyadi, beserta bapak Taufik Eko Susilo.

\section{Daftar Pustaka}

Bontrup, C., Taylor, W. R., Fliesser, M., Visscher, R., Green, T., Wippert, P., and Zemp, R. (2019). Low Back Pain and its Relationship with Sitting Behaviour Among Sedentary Office Workers. Applied Ergonomics, 81(July), 102894.

Bontrup, C., Taylor, W. R., Fliesser, M., Visscher, R., Green, T., Wippert, P., \& Zemp, R. (2019). Low Back Pain and its Relationship with Sitting Behaviour Among Sedentary Office Workers. Applied Ergonomics, $\quad$ 81(July), 102894. 
https://doi.org/10.1016/j.apergo.2019.1028 94

Dagne, D., Abebe, S. M., \& Getachew, A. (2020). Work-Related Musculoskeletal Disorders and Associated Factors Among Bank Workers in Addis Ababa, Ethiopia : A Cross-Sectional Study. Environmental Health and Preventive Medicine, 5(33), 18.

Davies, K. A. B., Pickles, S., Sprung, V. S., Kemp, G. J., Moore, D. R., Tahrani, A. A., \& Cuthbertson, D. J. (2019). Reduced Physical Activity in Young and Older

Adults : Metabolic and Musculoskeletal Implications. Therapeutic Advances in Endocrinology and Metabolism, 10, 1-15. https://doi.org/10.1177/2042018819888824

Desai, V. S., \& Anand, S. (2020). Prevalence of Piriformis Tightness With Relevance of Sitting Duration in Bankers. Indian Journal of Forensic Medicine \& Toxicology, 14(3), 749-754.

Gupta, N., Christiansen, C. S., Hallman, D. M., Korshøj, M., Carneiro, I. G., \& Holtermann, A. (2015). Is Objectively Measured Sitting Time Associated with Low Back Pain? A Cross-Sectional Investigation in the NOMAD Study. Plos One, 10(3), 1-18. https://doi.org/10.1371/journal.pone.01211 59

Hanna, F., Daas, R. N., El-Shareif, T. J., AlMarridi, H. H., Al-Rojoub, Z. M., \& Adegboye, O. A. (2019). The Relationship Between Sedentary Behavior, Back Pain, and Psychosocial Correlates Among University Employees. Frontiers in Public Health, 7, 1-7. https://doi.org/10.3389/fpubh.2019.00080

Hartvigsen, J., Hancock, M. J., Kongsted, A., Louw, Q., Ferreira, M. L., Genevay, S., ... Karppinen, J. (2018). What Low Back Pain is and Why We Need to Pay Attention. The Lancet, $\quad 391(18), \quad$ 2356-2367. https://doi.org/10.1016/S0140-
R.G Junita., A Pristianto., A Supriyadi. \& T.E Susilo Fisiomu.2021 Vol 2(3): 150-161 6736(18)30480-X

DOI: $10.23917 /$ fisiomu.v2i3.15199

Kanyenyeri, L., Asiimwe, B., Mochama, M., \& Nyiligira, J. (2017). Prevalence of Back

Pain and Associated Factors Among Bank Staff in Selected Banks in Kigali , Rwanda: A Cross Sectional Study. Health Science Journal, 11, 1-7. https://doi.org/10.21767/1791-

809X.1000505

Karunanayake, A. L., Pathmeswaran, A., Kasturiratne, A., \& Wijeyaratne, L. S. (2013). Risk Factors for Chronic Low back Pain in a Sample of Suburban Sri Lankan Adult Males. International Journal of Rheumatic Diseases, 16, 203-210.

Korshøj, M., Jørgensen, M. B., Hallman, D. M., Olsen, J. L., Holtermann, A., \& Gupta, N. (2018). Prolonged Sitting at Work is Associated with a Favorable Time Course of Low-Back Pain Among Blue-Collar Workers: A Prospective Study in the DPhacto Cohort. Scandinavian Journal of Work, Environment and Health, 44(5),530538. https://doi.org/10.5271/sjweh.3726

Madinei, S., Motabar, H., \& Ning, X. (2018). The Influence of External Load Configuration on Trunk Biomechanics and Spinal Loading During Sudden Loading.

Ergonomics, 61(10), 1364-1373. https://doi.org/https://doi. org/10.1080/00140139.2018.1489068

Magnon, V., Dutheil, F., \& Auxiette, C. (2018). Sedentariness: A need for a Definition. Frontiers in Public Health, 6, 55-58. https://doi.org/10.3389/fpubh.2018.00372

Mbada, C., Olaogun, M., Oladeji, O., Omole, J., \& Ogundele, A. (2016). Biomechanical Effect of Sitting Postures on Sitting Load and Feet Weight in Apparently Healthy Individuals. Nigerian Journal of Health Sciences, 16(1), 15-21. https://doi.org/10.4103/1596-4078.190030

Mondal, M., Sarkar, B., Alam, S., Das, S., Malik, K., Kumar, P., \& Sahay, P. (2017). 
Prevalence of Piriformis Tightness in Healthy Sedentary Individuals : A Cross Sectional Study. International Journal of Health Sciences and Research, 7, 134-142. Morris, L. D., Daniels, K. J., Ganguli, B., \& Louw, Q. A. (2018). An Update on the Prevalence of Low Back Pain in Africa : A Systematic Review and Meta-Analyses. BMC Musculoskeletal Disorders, 19, 1-15. Muralidharan, D., Fareed, N., \& Shanthi, M. (2013). Musculoskeletal Disorders among Dental Practitioners: Does It Affect Practice? Epidemiology Research International, 1-6.

O'sullivan, P., Smith, A., Beales, D., \& Straker, L. (2017). Understanding Adolescent Low Back Pain From a Multidimensional Perspective: Implications for Management. Journal of Orthopaedic \& Sports Physical Therapy, 47(10), 741-751. https://doi.org/10.2519/jospt.2017.7376

Pillai, D., \& Haral, P. (2018). Prevalence of Low Back Pain in Sitting Vs Standing Postures in Working Professionals in the Age Group of 30-60. International Journal of Health Sciences and Research, 8, 131-137.

Šagát, P., Bartík, P., González, P. P., Tohănean, D. I., \& Knjaz, D. (2020). Impact of COVID-19Quarantine on Low Back Pain Intensity, Prevalence, and Associated Risk Factors Among Adult Citizens Residing in Riyadh (Saudi Arabia): A Cross-Sectional Study. International Journal of Environmental Research and Public Health, 17(19), 1-13.
R.G Junita., A Pristianto., A Supriyadi. \& T.E Susilo Fisiomu.2021 Vol 2(3): 150-161 DOI: $10.23917 /$ fisiomu.v2i3.15199 https://doi.org/10.3390/ijerph17197302

Soares, C. O., Pereira, B. F., Gomes, M. V. P., Marcondes, L. P., Gomes, F. de C., \& Melo-Neto, J. S. de. (2019). Preventive factors against work-related musculoskeletal disorders: narrative review. Revista Brasileira de Medicina Do Trabalho, 17(3), 415-430. https://doi.org/10.5327/Z16794435201903 60

Stamatakis, E., Gale, J., Bauman, A., Ekelund, U., Hamer, M., \& Ding, D. (2019). Sitting Time, Physical Activity, and Risk of Mortality in Adults. American College of Cardiology, 73(16). https://doi.org/10.1016/j.jacc.2019.02.031

Thivel, D., Tremblay, A., Genin, P. M., \& Panahi, S. (2018). Physical Activity, Inactivity, and Sedentary Behaviors: Definitions and Implications in Occupational Health. Occupational Health and Physical Activity, 6(288), 1-5. https://doi.org/10.3389/fpubh.2018.00288

Wang, M., Yu, J., Liu, N., Liu, Z., Wei, X., Yan, F., \& Yu, S. (2017). Low Back Pain Among Taxi Drivers: A Cross-Sectional Study. Occupational Medicine, 67, 290295.

https://doi.org/10.1093/occmed/kqx041

Warner, S., Munawar, A., Ahmad, A., Fatima, M., \& Waqas, M. (2018). Prevalence of piriformis syndrome among university of Lahore male students. Rawal Medical Journal, 43(2), 306-308. 